\title{
INFRARED REFLECTANCE OF GaP NANORODS
}

\author{
M. Treideris, I. Šimkienė, I. Kašalynas, A. Selskis, and G.J. Babonas \\ Semiconductor Physics institute, Center for Physical Sciences and Technology, A. Goštauto 11, LT-01108 Vilnius, \\ Lithuania \\ E-mail: marius@pfi.lt
}

Received 12 September 2011; accepted 1 December 2011

\begin{abstract}
The reflectance of GaP nanorods on GaP substrates was investigated in the frequency range of $300-500 \mathrm{~cm}^{-1}$ by Fourier transform infrared (FTIR) reflectance spectroscopy. GaP nanorods were fabricated by the anodic electrochemical etching technique. The structure of nanorods, formed by using galvanostatic and potentiostatic etching regimes was studied by the SEM technique. The correlation between particular features in the infrared reflection spectra in the reststrahlen region and the morphology of nanorods was analysed and discussed.
\end{abstract}

Keywords: III-V semiconductors, nanorods, infrared spectra

PACS: 78.66.Sq, 81.07.-b, 81.70.Fy

\section{Introduction}

Recently, a large attention has been paid to porous semiconductors, which show potential applications in the development of optoelectronic devices [1]. A particular interest was due to enhanced photoluminescence [2] and nonlinear effects [3] in porous semiconductors, as compared to bulk samples. In particular, porous $\mathrm{GaP}$ (por- $\mathrm{GaP}$ ) and $\mathrm{GaP}$ nanorods are considered as prospective materials for antireflection coatings [1] and as a pattern for organic cell deposition [4].

The optical studies of por-GaP in the infrared (IR) range have been carried out mainly by the Raman technique (see, e. g., [5-7]). The most interesting feature observed was due to Fröhlich modes in the spectral range between transverse optical (TO) and longitudinal optical (LO) excitations and their $\mathrm{L}-\mathrm{T}$ splitting [5]. IR reflection was investigated in por-GaP formed in $\mathrm{H}_{2} \mathrm{SO}_{4}$-based $[5,6]$ and HFbased [8] acid electrolytes.

The goal of the present work was to fabricate the $\mathrm{GaP}$ nanorods by using the electrochemical etching technique and to investigate the IR response of $\mathrm{GaP}$ nanorods.

\section{Experiment}

$\mathrm{GaP}$ nanorods were formed by electrochemical anodic etching of $300-\mu \mathrm{m}$-thick wafer of $n-\mathrm{GaP}$ with S-donor density $(5.0-5.3) \cdot 10^{17} \mathrm{~cm}^{-3}$. The wafers were cleaned in hot isopropyl/ethanol and washed in distilled water. Etching was carried out in dark by exposing the (111) face of c-GaP to electrolyte. The ethanol solution of $3 \mathrm{M} \mathrm{HNO}_{3}$ electrolyte was used. The backside contact was made by means of In-Ga eutectics and graphite electrode. The Pt-electrode was used as cathode in the electrolyte etching cell. The etching area of $\mathrm{GaP}$ was $6 \mathrm{~mm}$ in diameter. The galvanostatic etching conditions (sample 1) were realised by using potentiostat Autolab PGSTAT 302 at constant current density $j=80 \mathrm{~mA} / \mathrm{cm}^{2}$. The potentiostatic etching conditions (sample 2) were realised by voltage source at $U=23 \mathrm{~V}$. The etching time was $1 \mathrm{~h}$. After the formation of por-GaP layer, the oxide layer on the top of the structure was removed in $30 \% \mathrm{KOH}$ solution.

The surface and cross-section morphology of $\mathrm{GaP}$ nanorods were studied making use of a scanning electron microscope (SEM) EVO 50 EP (Carl Zeiss SMT). The IR reflectance spectra were meas- 
ured in the region of $300-500 \mathrm{~cm}^{-1}$ using a Nicolet 8700 FTIR spectrometer equipped with a specular reflectance unit with the reflection angle $22^{\circ}$.

\section{Results and discussion}

The structural studies showed that under galvanostatic and potentiostatic etching conditions nanorods of 3-10 $\mu \mathrm{m}$ in height and $100-400 \mathrm{~nm}$ in width were formed (Fig. 1). For the first time, the GaP nanorods were formed by electrochemical etching.

In previous works $[9,10]$ it was noted that etching in the $3 \mathrm{M} \mathrm{HNO}_{3}$ aqueous solution led to the growth of the oxide layer only, and a porous layer did not form. However, using the $3 \mathrm{M} \mathrm{HNO}_{3}$ ethanol

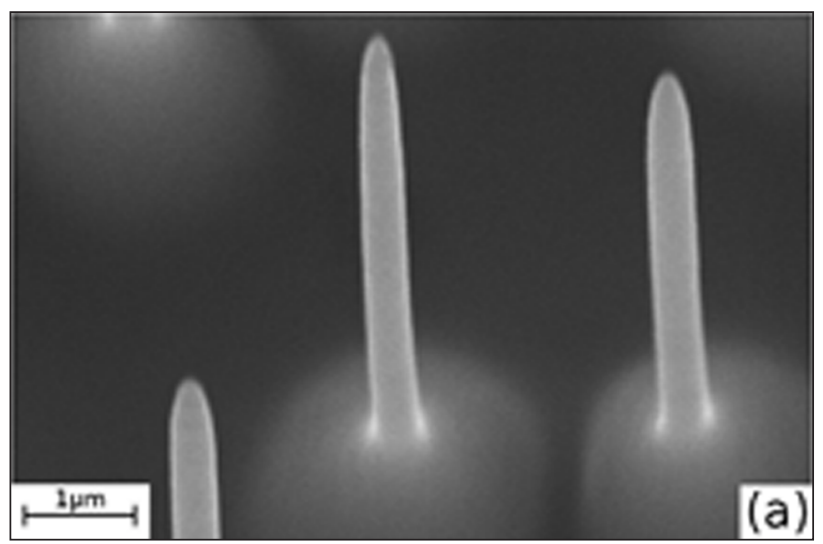

solution, the nanorods were formed as discussed previously. It can be assumed that in this case ethanol acts as a stabiliser, preventing the formation of branches and favouring the increase of the pore diameter. When the pore walls become thin enough, resistance increases significantly, and the etching rate decreases. Nanorods originate from these thin walls during the further etching process. The height, diameter and concentration of nanorods depend on the etching conditions. By using different applied potentials, the nanorods of various height, width and concentration can be formed.

The typical IR reflection spectra of the investigated samples in the reststrahlen region are presented in Fig. 2(a). In the spectra of the normalised

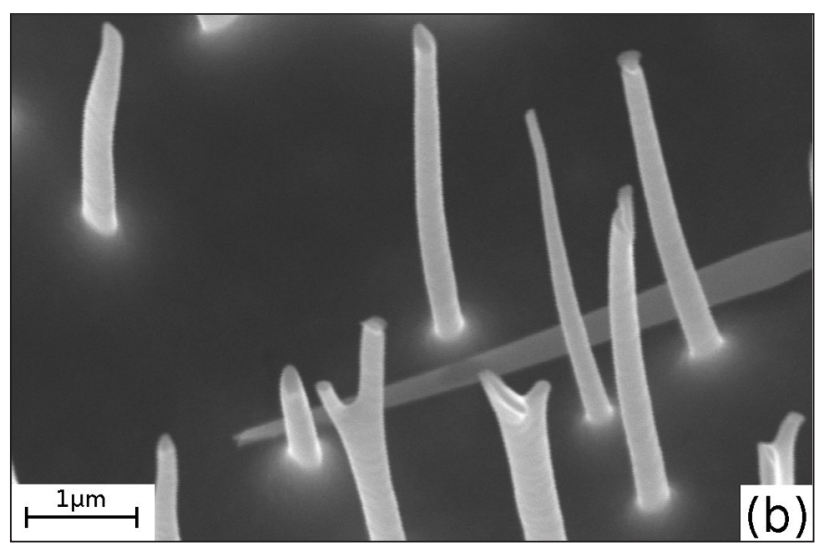

Fig. 1. SEM micrographs of GaP nanorods produced in (a) galvanostatic and (b) potentiostatic regime. Bars correspond to $1 \mu \mathrm{m}$.
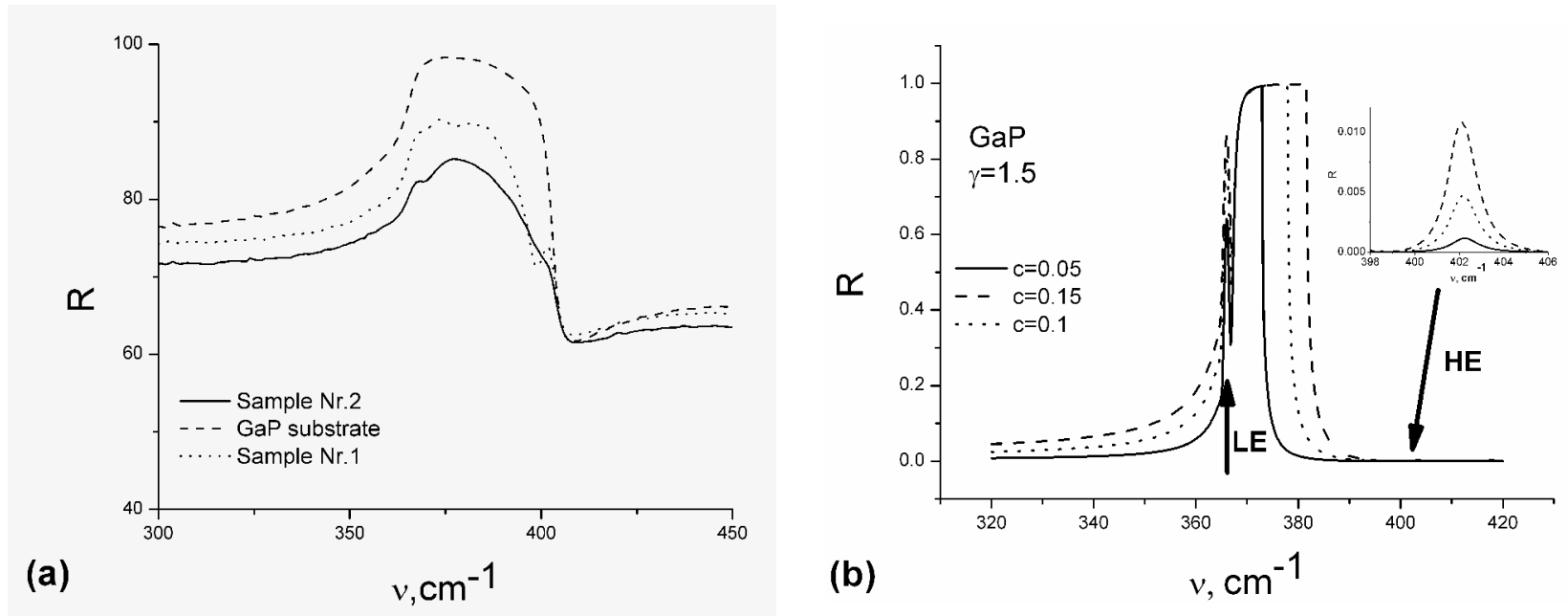

Fig. 2. (a) Reflectance spectra of c-GaP and por-GaP with nanorods. (b) Modelled reflectance spectra. 
reflection coefficient $R_{\text {norm }}(\omega)$, two bands, low(LE) and high-energy (HE), appeared for nanorods formed using both etching conditions. The origin of the fine structure in the reflection spectra follows from model calculations (Fig. 2(b)). The reflection spectra have been calculated in the model developed in [5] with electronic dielectric function $\varepsilon_{\infty}=9.036$ [11] and the energies of TO- and LO-modes equal to 366 and $402.3 \mathrm{~cm}^{-1}$ [5], respectively:

$$
\varepsilon(\omega)=\varepsilon_{\infty}\left(1+\frac{\omega_{\mathrm{LO}}^{2}-\omega_{\mathrm{TO}}^{2}}{\omega_{\mathrm{TO}}^{2}-\omega^{2}-\mathrm{i} \omega \gamma}\right) .
$$

The relative volume concentration $c=V_{\mathrm{GaP}} / V_{\text {air }}$ and damping $\gamma$ were treated as free parameters. The $\mathrm{LE}$ band in reflection spectra originates from $\mathrm{GaP}$ TO phonon whereas the $\mathrm{HE}$ band is related to $\mathrm{GaP}$ LO phonon and to Fröhlich TO- and LO-modes.

On the basis of the model calculations (Fig.2(b)), the correlation between the reflection spectra and morphology of the samples under consideration were revealed. It should be emphasized that a decrease of the volume concentration of $\mathrm{GaP}(c$ parameter) results in the decrease of the HE-side of the reststrahlen band. Therefore, the difference in the spectra for samples 1 and 2 is caused by the volume concentration of nanorods. From the structure investigations, the estimated $c$-value was 0.1 and 0.08 for samples 1 and 2, respectively. Also, the HE band was masked in the spectrum of sample 2. This feature can be due to irregularities in the nanorod shape in this sample which results in the increase of the damping parameter $\gamma$ and broadening of the HE-band.

As follows from model calculations (Fig. 2(b)), the intensity of the LE band decreases when the volume concentration of $\mathrm{GaP}$ (c-parameter) is decreased. This also explains differences in sample 1 and sample 2 spectra. The $c$-parameter of sample 2 is smaller, so the intensity of the LE band is smaller.

\section{Conclusions}

$\mathrm{GaP}$ nanorods were made by electrochemical etching for the first time. The nanorods of 3-10 $\mu \mathrm{m}$ in height and 100-400 $\mathrm{nm}$ in width were more regular in por-GaP sample fabricated in galvanostatic regime as compared to that formed in potentiostatic regime.
$\mathrm{GaP}$ nanorods were characterised by the FTIR technique. A complex structure due to LO, TO and Fröhlich modes were seen in IR spectra. The particular features in IR reflection spectra correlate with the morphology of samples and are well interpreted by the modelled spectra.

\section{References}

[1] H. Föll, J. Carstensen, and S. Frey, Porous and nanoporous semiconductors and emerging applications, J. Nanomater. ID 91635 (2006).

[2] K. Tomioka and S. Arachi, Structural and photoluminescence properties of porous $\mathrm{GaP}$ formed by electrochemical etching, J. Appl. Phys. 98(7) (2005).

[3] L.A. Golovan, G.L. Petrov, G.Y. Fang, V.A. Melnikov, S.A. Gavrilov, A.M. Zheltikov, V.Y. Timoshenko, P.K. Kashkarov, V.V. Yakovlev, and C.F. Li, The role of phase-matching and nanocrystal-size effects in three-wave mixing and CARS process in porous gallium phosphide, Appl. Phys. B 84, 303-308 (2006).

[4] W. Hällström, T. Mårtensson, Ch. Prinz, P. Gustavsson, L. Montelius, L. Samuelson, and M. Kanje, Gallium phosphide nanowires as a substrate for cultured neurons, Nano Lett. 7, 29602965 (2007).

[5] A. Sarua, J. Monecke, G. Irmer, I.M. Tiginyanu, G. Gärtner, and H.L. Hartnagel, Fröhlich modes in porous III-V semiconductors, J. Phys. Condens. Matter 13, 6687-6706 (2001).

[6] N. Dmitruk, T. Barlas, I. Dmitruk, S. Kutovyi, N. Berezovska, J. Sabataityte, and I. Simkiene, IR reflection, attenuated total reflection, and Raman scattering of porous polar III-V semiconductors, Phys. Status Solidi B 247(4), 955-961(2010).

[7] P.C. Ricci, A. Anedda, C.M. Carbonaro, D. Chiriu, F.Clemente, and R.Corpino, Photo-electrochemical formation of porous GaP, Phys. Status Solidi C 2(9), 3365-3369 (2005).

[8] A. Belogorokhov, Yu.A. Pusep, and L. Belogorokhova, Fourier-transform infrared reflection study of the morphology of porous semiconductor structures, J. Phys. Condens. Matter 12, 3897-3900 (2000).

[9] Y.C. Shen, M.H. Hon, I.C. Leu, and L.G. Teoh, Electrochemical formation and microstructure of porous gallium phosphide, Appl. Phys. A 98, 429434 (2010).

[10]R.W. Tjerkstra, Electrochemical formation of porous $\mathrm{GaP}$ in aqueous $\mathrm{HNO}_{3}$, Electrochem. Solid State Lett. 9, C81-C84 (2006).

[11]D.A. Yas'kov and A.N. Pikhtin, Optical properties of gallium phosphide grown by floating zone I. Refractive index and reflection coefficient. Mater. Res. Bull. 4, 781-788 (1969). 


\section{GaP NANOSTRYPELIŲ INFRARAUDONASIS ATSPINDYS}

M. Treideris, I. Šimkienė, I. Kašalynas, A. Selskis, G.J. Babonas

Fiziniu ir technologijos mokslu centro Puslaidininkiu fizikos institutas, Vilnius, Lietuva

\section{Santrauka}

Aprašyta n-GaP (S) nanostrypelių formavimo elektrocheminio èsdinimo būdu $3 \mathrm{M} \mathrm{HNO}_{3}$ etanolio elektrolite technologija. Šiuo būdu pirmą kartą suformuoti 3-10 $\mu \mathrm{m}$ aukščio ir (100-400) nm skersmens $n$-GaP nanostrypeliai. Aptarti darinių, gautų èsdinant galvanostatiniame ir potenciostatiniame režime, morfologijos skirtumai. GaP dariniai su nanostrypeliais buvo tiriami nuskaitančio elektroninio mikroskopo ir atspindžio IR (300-500) $\mathrm{cm}^{-1}$ spektro ruože metodais. Išanalizuoti IR spektrų ypatumai bei jų koreliacija su nanostrypelių morfologija. 